\title{
GEOLOGY OF THE SOUTHERN AMAZON CRATON IN SOUTHWESTERN MATO GROSSO, BRAZIL: A REVIEW
}

\section{JAYME ALFREDO DEXHEIMER LEITE AND GÉRSON SOUZA SAES}

\begin{abstract}
The southern Amazon Craton in Mato Grosso, is reviewed in light of more recent geological, petrological, structural and geochronological data. Jaurú and Rio Alegre terranes, the Santa Helena Granite Complex and the Aguapeí Belt are the major tectonic units of the area. The Jaurú terrain consists of MORB suite and arc basalts with minor chert and felsic volcanics, calc-alkaline tonalites, orthogneisses, and migmatites of ca. $1.78 \mathrm{Ga}$. Two well-marked granitic events occurred in this terrain between 1.55 to $1.48 \mathrm{Ga}$ (the Cachoeirinha magmatic arc) and close to $1.0 \mathrm{Ga}$ (the Guapé Intrusive Suite). The Rio Alegre terrain consists of mafic volcanics and ultramafic intrusives with minor chert and tonalite intrusions and its minimum age is given $1.55 \mathrm{Ga}$ tonalites. The Santa Helena Granite Complex (1.45 Ga) is a NW-trending, A-type, hornblende-biotite syenogranite batholith with abundant xenoliths of older rocks and emplaced between the Rio Alegre and Jauru terranes. The Aguapeí Belt is a narrow NW-trending zone that follows the limits between the Rio Alegre terrain and the Santa Helena Complex. It consists of low-grade, folded shallow marine to fluvial sediments. The Jaurú Terrain is interpreted as representing an island arc and the Rio Alegre as ophiolite, both with an age between $1.9 \mathrm{Ga}$ and $1.55 \mathrm{Ga}$. The Cachoeirinha magmatic arc of ca. $1.55 \mathrm{Ga}$ is likely to result from the amalgamation of these two terranes. The suture between the Rio Alegre and Jaurú terranes was intruded by the Santa Helena Granite Complex at about $1.45 \mathrm{Ga}$. The youngest events $(1.2 \mathrm{Ga}$ to $1.0 \mathrm{Ga})$ are represented in the Aguapeí Belt, by extensional reactivation, intracontinental rifting, sedimentation, deformation, and low-grade metamorphism, and are correlated to the Sunsas Orogeny of eastern Bolivia.
\end{abstract}

Keywords:

INTRODUCTION

The Amazon Craton (Fig.1a) has an area of aboeafter considered as the southern portion of the Amazon Craton, the main subject of this contribution.

Researches in this area date back at least to the 50's with reconnaissance and a few regional surveys (Almeida 1964, Figueiredo et al.1974), and followed by detailed geological mapping (Monteiro et al.1986, and more than 15 field surveys by undergraduate students of the Geology Department of the Federal University of Mato Grosso), as well as MSc and PhD thesis (Carneiro 1985, Leite 1989, Matos 1991, Pinho 1993, Ruiz 1992, Pinho 1996, Geraldes 1996, Saes 1999). As a result, a large amount of new data became available that constrained evolution models for the area (Cordani et al.1979, Cordani and Brito Neves 1982, Teixeira et al.1989, Carneiro et al.1992, Saes and Fragoso César 1994, 1996, Tassinari et al.1996, Sadowski and Bettencourt 1996, Tassinari and Macambira 1999) leading to a better understanding of the complexity of this key Paleo-Mesoproterozoic are of the South American Continent. This contribution aims to present the state-of-the-art of the geological, geochronological, petrological, tectonic, and structural data and stress some constraints to the evolution models.

GEOLOGY OF THE SOUTHERN AMAZON CRATON The area under consideration includes southwestern Mato Grosso and contains several rock associations that differ in age, petrologic evolution, and tectonic settings. They comprise (Fig.2) the Jaurú and Rio Alegre terranes (Saes and Fragoso Cesar 1996), the Santa Helena Granite Complex (Saes et al.1984, Leite 1989) and the Aguapeí Belt (Saes and Leite 1993).

The Jaurú Terrain The Jaurú Terrain consists of volcanosedimentary sequences, tonalite intrusions, orthogneisses, migmatites, syn- to late-kinematic granitoids, younger and undeformed granitoids, and basic sills. The oldest unit of this terrain comprises three NW-SE trending volcano-sedimentary belts with lower sub-aqueous to subaerial basaltic flows interlayered with minor chert and banded iron formations, upper intermediate to felsic flows, and peridotite to gabbro intrusions. From east to west, these belts are named as Quatro Meninas, Araputanga and Cabaçal (Saes et al.1984, Leite et al.1986, Leite 1989), and are grouped under the Alto Jauru Greenstone Belt (Pinho et al.1997). The belts are intruded by NW-trending, elongated tonalites with abundant xenoliths of mafic rocks. Geochemical data (Leite 1989, Pinho et al.1997) show that the mafic volcanic rocks have an easterly trend from mid-ocean ridge to arc-related basalts, while the tonalite bodies are arc-derived (Pinho et al.1997). SHRIMP U-Pb zircon data of the Cabaçal tonalite (Pinho 1996) yield a ${ }^{207} \mathrm{~Pb} /{ }^{206} \mathrm{~Pb}$ age of $1.78 \pm$ $10 \mathrm{Ga}$, interpreted as the crystallization age of the intrusion.

Orthogneisses and migmatites crop out as cores of dome-like structures in the flanks of and between the belts, and are known under different names, depending on the locality (Brigadeirinho Gneiss Complex of Saes et al.1984, Quatro Marcos Gneiss of Carneiro 1985 and Carneiro et al.1992, Rio Vermelho Gneissic Complex of Leite
1989). These complexes have been interpreted as resulting from deformation and metamorphism at the roots of the volcanosedimentary belts. Geochronological data include one $\mathrm{Pb} / \mathrm{Pb}$ isochron of $1.717 \pm 120 \mathrm{Ma}$ with a single stage model $\mu 1$ value of 8.09 (Tassinari et al.1996) and a ${ }^{207} \mathrm{~Pb} /{ }^{206} \mathrm{~Pb}$ age of $1.795 \pm 10 \mathrm{Ma}$ (Geraldes et al.1999). Carneiro (1985) obtained a Rb-Sr isochron age of $1.961 \mathrm{Ma}$ and low initial ${ }^{87} \mathrm{Sr} /{ }^{86} \mathrm{Sr}$ ratio of 0.702 for gneisses of the area.

Late to post-kinematic granitoids within this terrain include the Alvorada and Cachoeirinha granites and the Água Clara Granodiorite (Saes et al.1984, Monteiro et al.1986, Leite 1989, Ruiz 1991, Geraldes et al.1997, Saes 1999). The granites are medium- to coarse-grained, vary from isotropic to strongly foliated, and span for ca. $70 \mathrm{Ma}$, between 1.55 and $1.48 \mathrm{Ga}$ (Geraldes et al.1999). Geochemically, they have a calc-alkaline arc signature (Pinho 1996 and Pinho et al.1997).

The younger granites of the Jaurú Terrain, collectively reported as the Guapé Intrusive Suite (Barros et al.1982, Saes et al.1984, Leite 1989), occur mainly along the Indiavaí-Lucialva Shear Zone as circular stocks mostly of granodiorite with a within-plate calk-alkaline trend (Menezes et al.1993). Only Rb-Sr geochronological data are available for these granites, and yielded ages between $1.0 \mathrm{Ga}$ and $0.9 \mathrm{Ga}$, which corresponds to the late stages of the Sunsas orogeny in eastern Bolivia (Litherland et al.1986). Differentiated mafic sills, known as the Rio Branco Intrusive Suite (Leite et al. 1985) occur in eastern Jaurú Terrain. They consist of fine-grained olivine gabbro, followed by gabbro and quartz gabbro and thin layers of quartz-syenite and granophyre. Geochronological data include a $\mathrm{Rb}$-Sr isochronic age of $1.1 \mathrm{Ga}$ and high initial ${ }^{87} \mathrm{Sr} /{ }^{86} \mathrm{Sr}$ ratio of 0.734 . U-Pb zircon ages of ca. $1.45 \mathrm{Ga}$ are presented by Geraldes et al. (1999) for this unit.

The Rio Alegre Terrain This terrain occurs as a narrow belt flooring the central zone of the Aguapeí Aulacogen (Saes and Fragoso César 1996) and is limited by sub-parallel N20W-trending faults. The eastern faults approximately coincide with the Aguapeí tectonic front, while the western, close to the Bolivian border, are less precisely mapped due to the sedimentary cover of Pantanal Matogrossense wetlands and of the Alto Guaporé river.

This terrain consists dominantly of metamorphosed maficultramafic rocks and rare felsic rocks. They include peridotite, pyroxenite, gabbro, basalts, and dacites (Figueiredo et al.1974, Barros et al.1982, Monteiro et al.1986, Matos 1994, Angeli et al.1997). The mafic volcanic rocks contain thin intercalations of chemical and clastic sedimentary rocks (Leite et al.1986, Matos 1994). Granitoid intrusions in this terrain are of tonalite with minor granodiorite and granite, which crop out along the Aguapeí River and the Aguapeí Tectonic Front (Pinho 1990, Saes and Leite 1993, Geraldes 1996). Geochemically, the mafic rocks have a tholeiitic to calk-alkaline trend of back-arc ocean floor tectonic setting (Pinho 1990, Matos and Schorscher 1997). Chemical and petrographic data of metaultramafic rocks led Angeli et al. (1997) to correlate them with the basal sections of an ophiolite. Geochronological data are scarce and were mostly obtained from 


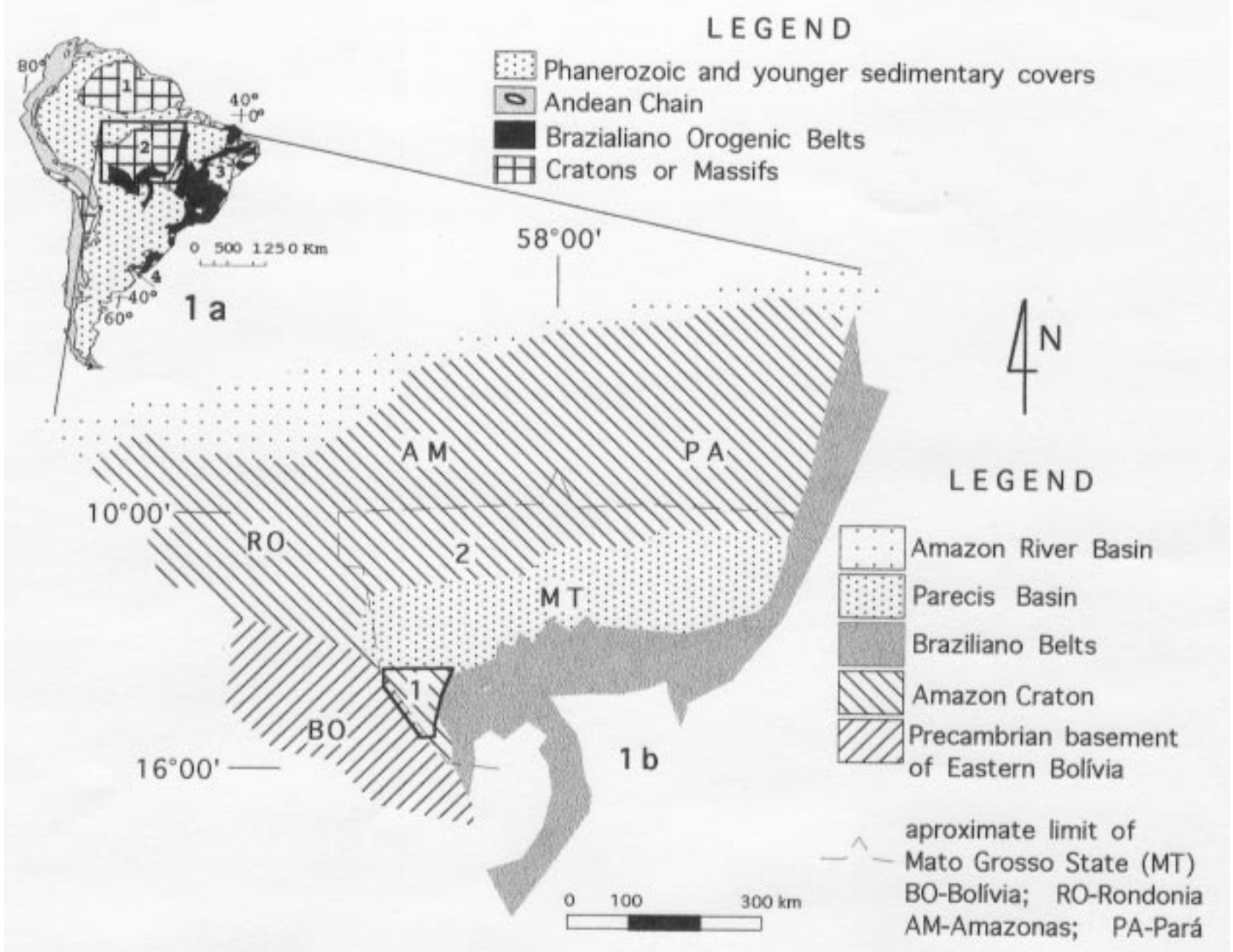

Figure 1 - (a) Main tectonic units of the South American Platform and location map of the Amazon Craton. 1) Guyana Shield, 2) Guaporé Shield, 3) Sao Fransisco Craton and 4) Rio de La Plata Craton. (b) Location of the studied area (dotted) and the main limits of the southern Amazon Craton in Mato Grosso.

intrusive granitoids (Geraldes et al.1999) which yielded a range between 1.55 and $1.42 \mathrm{Ga}$, the older age indicating the minimum age of the Rio Alegre Terrain.

The Santa Helena Granite Complex The Santa Helena Complex occurs in a northwest-trending area of about $6,000 \mathrm{~km}^{2}$ between the Jaurú and Rio Alegre terranes. To the west, it is roughly limited by the 1.2-1.0 Ga Aguapeí tectonic front, but some outcrops occur farther west where its intrusive contacts are clearly exposed. Its eastern limit was originally traced at the Indiavaí-Lucialva Shear Zone (Saes et al.1984, Leite 1989, Saes and Fragoso Cesar 1996, Geraldes et al.1999), but it also crops out farther east. To the north and south, younger sedimentary covers conceal the complex.

The batholith is compositionally homogeneous and consists of hornblende-biotite syenogranite with a conspicuous N20W-trending metamorphic foliation. Near the Indiavaí-Lucialva Shear Zone and the Aguapeí Tectonic Front, the granite turns into protomylonite, mylonite, and augen gneisses. Contact relationships indicate that the complex intrudes the gneisses of the Brigadeirinho Complex and the mafic and ultramafic rocks of the Quatro Meninas and Araputanga belts of the Jaurú Terrain.

Geochemically, the intrusion has high $\mathrm{Na}_{2} \mathrm{O}+\mathrm{K}_{2} 0$, low $\mathrm{Al}_{2} \mathrm{O}_{3}$, very low $\mathrm{CaO}$ and high total REE, which led Menezes et al.(1993) to intepret it as an A-type granite, but Geraldes et al.(1997) suggest that this granite has a calk-alkaline trend.

The Santa Helena Complex yielded a Rb-Sr isochronic age of 1.308 $\pm 45 \mathrm{Ma}$ and high initial ${ }^{87} \mathrm{Sr} /{ }^{86} \mathrm{Sr}$ ratio of 0.715 (Menezes et al. 1993), which agrees with a crustal reworking origin. U-Pb data of zircon yielded an age of $1.450 \pm 2 \mathrm{Ma}$, with inherited core of $2.82 \mathrm{Ga}$ (Geraldes et al.1997) that confirms the participation of an important older crustal component. Th age interval of the Camplex (1.45 to 1.3 $\mathrm{Ga}$ ) is roughly coeval with the Rondonian-San Ignácio Orogeny, considered to have evolved under ensialic conditions (Tassinari et al.1996).

The Aguapeí Belt The Aguapeí Belt is a sedimentary basin that overlaps the limits of previously accreted terranes. Its evolution starts with the extensional reactivation of the southern margin of the Amazon Craton and formation of an intracontinental rift (Aguapeí Aulacogen) after 1.2 Ga (Litherland et al.1989, Saes and Fragoso César 1994, 1996). The thick siliciclastic sedimentary record indicates that the basin evolved under a rift, sineclise, and inversion stages.

The Aguapeí Belt occurs as a NW-trending narrow zone of intense deformation and very low metamorphic grade along the central parts of the area, roughly coinciding with the limits between the Rio Alegre terrain and the Santa Helena Granitic Complex. Regionally, its deformation seems to reflect a large dextral transpression zone. At a local scale, oblique high-angle northeast-verging thrusts and low angle nappes dominate, and are correlated with Sunsas Orogeny, between 1.2 $\mathrm{Ga}$ and $1.0 \mathrm{Ga}$, of eastern Bolivia.

TECTONIC MODELS Several tectonic models have been proposed to explain the evolution of the southern Amazon Craton. (Teixeira et al.1989, Tassinari et al.1996, Saes and Fragoso César 1994, 1996, Geraldes 1999).

Teixeira et al. (1989), Tassinari (1984), Tassinari et al. (1996) and Tassinari and Macambira (1999) interpret the tectonic evolution of the Amazon Craton on a continental scale under a continuous westward amalgamation of Paleoproterozoic (Ventuari-Tapajós Province) to 


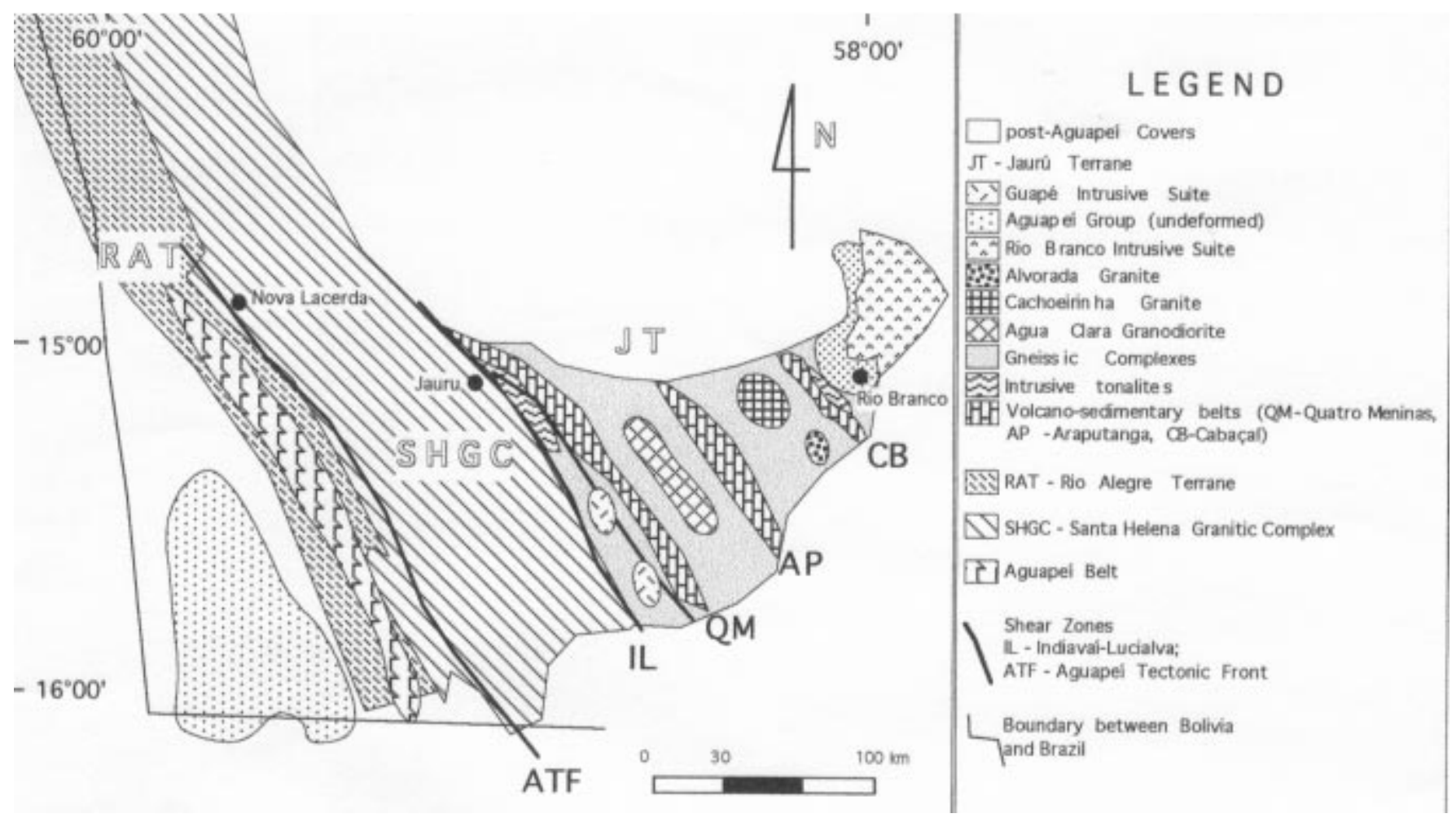

Figure 2 - Geological sketch of the southern Amazon Craton in Mato Grosso.

Mesoproterozoic (Rio Negro-Juruena Province) magmatic arcs onto the Archean Central Amazonia Province block. The westernmost provinces (Rondonian-San Ignácio and Sunsas) expose basement rocks belonging to the Rio Negro-Juruena Province and are, therefore, interpreted as having, in part, evolved as ensialic (Teixeira et al.1989, Tassinari et al.1996). These authors argue that the geology of the southern portion of the Amazon Craton exposed in southwestern Mato Grosso and Rondonia, corresponds to the southeastern extension of the Rio Negro-Juruena and Rondonia-San Ignácio provinces, as indicated by the common northwest-southeast structural trends, age range (1.75 Ga to $1.4 \mathrm{Ga}$ ), positive eNd(t), low ${ }^{87} \mathrm{Sr} /{ }^{86} \mathrm{Sr}$ initial and tectonic environment allover the province. On the other hand, isotopic data, time interval coherence between tonalites of the Jaurú $(1.7 \mathrm{Ga})$ and Rio Alegre Terranes $(1.55 \mathrm{Ga})$ and the granitoids of the Santa Helena Complex $(1.45 \mathrm{Ga})$, the calc-alkaline trend of most of the granitoids ant their low $\mathrm{T}_{\mathrm{m}}$ model ages and positive $\varepsilon \mathrm{Nd}$ values, in some cases with low ${ }^{87} \mathrm{Sr} r{ }^{88 \mathrm{~S}} \mathrm{Sr}$ initial ratios, led Geraldes et al. $(1997,1999)$ to propose that the Amazonian Craton in southwestern Mato Grosso resulted from the amalgamation of three magmatic arcs (Rio Alegre, Santa Helena and Cachoeirinha).

DISCUSSION After nearly 40 years of researches, the subdivision of the southern Amazon Craton in southwestern Mato Grosso based on lithological, structural, petrological, and geochronological data has reached a more consistent picture. However, many problems arise when evolution models are considered. One substantial aspect is the proposed extension of the Rio Negro-Juruena Province to southern Mato Grosso (Tassinari et al.1996, Geraldes et al.1999). This extension is not support by the following facts. First, the consistent structural trend described to extend all over the Rio Negro JuruenaProvince changes geographically. As shown by Santos et al. (1998) in eastern Rondonia and its extension to the Aripuanã-Juruena and Tabaporã areas in northwestern Mato Grosso, the trend of folds and foliations in both the basement and volcanic rocks is clearly E-W to WNW and not NW-SE as found in the Jaurú Terrain. Second, whilst plagioclase-poor granites dominate in the Rio Negro-Jurena Province, basalts and plagioclase-rich granitoids are major rocks in the Jaurú Terrain. Third, a major NW-SE structural break between the Rio Negro-Juruena Province and the southern portion of the Amazonian Craton occurs beneath the Parecis basin (Siqueira 1989, Leite et al.1999). Fourth, the tectonic regime changes along the proposed Rio
Negro-Juruena Province, as indicated by the contrasting regimes between the northern (Juruena area) and southern (Jaurú Terrain) portions of the Craton in Mato Grosso. In the Aripuanã and Roosevelt areas, an intracontinental rift formed at ca. $1.74 \mathrm{Ga}$, but at that time, an island-arc existed in the Cabaçal area (Pinho 1997). Fifth, in spite of the Rondonian Chronotectonic Province and the Santa Helena Granitc Complex being coeval, they do not have counterparts in Rondônia nor in northern Mato Grosso, but the later is similar, in age and composition, to the Pensamiento Granite Complex of eastern Bolívia. It seems, therefore, unlikely that the southern portion of the Amazon Craton is the extension of the northern.

Another conflicting point is the Geraldes et al.(1999) hypothesis according to which the southern Amazon Craton evolved by an eastward amalgamation of, at least, three magmatic arcs. At least for the Santa Helena batolith, the following features do not support the existence of one of the arcs: a) undeformed tonalites clearly associated to the Rio Alegre Terrain are coupled with the deformed and metamorphosed Santa Helena A-type granitoid, resulting in an apparent calc-alkaline trend misinterpreted as resulting from a ca. 1.45 Ga magmatic arc (Santa Helena volcano-plutonic arc of Geraldes et al.1999); b) felsic volcanic rocks interpreted as belonging to that arc are, actually, mylonites and ultramyllonites derived by shearing of the Santa Helena batholith, as clearly exposed along the highway BR-364 near Nova Lacerda; c) this indicates that the Santa Helena granite can not account for the origin of the proposed Cachoeirinha continental magmatic arc, and d) the Rio Alegre Terrain is dominated by ophiolitetype mafic and ultramafic rocks.

CONCLUSIONS The geologic framework of the southern Amazon Craton in Mato Grosso consists of a diversity of rock assemblage evolved under different tectonic settings within a timespan from ca $1.9 \mathrm{Ga}$ to ca $1.0 \mathrm{Ga}$. This area is, therefore, a key to the understanding of the Paleo-Mesoprotezoic reconstruction of the Rodinia supercontinent. The Jaurú and Rio Alegre terranes are older than $1.5 \mathrm{Ga}$ and their relationships with the Santa Helena Granite Complex indicate that they have been amalgamated prior to $1.45 \mathrm{Ga}$. Between $1.45 \mathrm{Ga}$ and ca $1.3 \mathrm{Ga}$, the suture zone between these terranes underwent intrusion by the A-type Santa Helena Granitic Complex, resulting in a continental mass whose relationships with the northern Amazon Craton are still unclear. The break up of this part of the continent gave rise to a rift, the Aguapeí Group (Saes and Fragoso César 1996). Closing of the continental margin during the Sunsas 
Orogeny formed the Aguapeí Belt, which coincide with the stabilization of the Amazon Craton as a whole.

Future questions to be answered include a global view of the studied area, its relationship with the northern Amazon Craton and the eastern Bolívia, problems related to the evolution of the Cachoeirinha magmatic arc (Geraldes et al.1999) and the complete evolution of Santa Helena Granite Complex.

Acknowledgements To two referees of RBG for critical analysis of the manuscript.

\section{References}

Almeida F.F.M. de (1964).Geologia do centro-oeste matogrossense. D.N.P.M., Div. Geol. Miner., Bol. 215, 137pp.Rio de Janeiro.

Angeli N., Grego M.I.B.M., Vidigal F.G., de Carvalho S.G. 1997. Pesquisa de Platinóides e Ouro no maciço metamáfico/ultramáfico do Morro do Leme, MT. In: SBG-Núcleo Centro-Oeste, Simpósio de Geologia do Centro-Oeste, 6, Cuiabá, Anais, p 49-51

Barros A.M., da Silva R.H., Cardoso O.R.F.A., Freire F.A., de Souza J.J.Jr., Rivetti M., da Luz D.S., Palmeira B., Tassinari C.C.G. 1982. Geologia da Folha Cuiabá SD 21 , Cuiabá. DNPM/Projeto RADAMBRASIL, Rio de Janeiro, pp. 25-192

Carneiro M.A.(1985). Contribuição à geologia da região de Quatro Marcos, MT. Instituto de Geociências, Universidade de São Paulo, São Paulo, Dissertação de Mestrado, $156 \mathrm{pp}$.

Carneiro M.A., Ulbrich H.H.G.J., Kawashita K. 1992. Proterozoic crustal evolution at the southern margin of the Amazon Craton in the State of Mato Grosso, Brazil: evidence from Rb-Sr and K-Ar data. Precambrian Research, 59:263-282

Cordani U.G. \& Brito Neves B.B.de 1982. The geologic evolution of South America during the Archean and Early Proterozoic. Revista Brasileira de Geociências, 12:78-88

Cordani U.G., Tassinari C.C.G., Teixeira W., Basei M.A.S., Kawashita K. 1979. Evolução tecônica da Amazônia com base nos dados geocronológicos. In: Congresso Geológico Chileno, 2, Arica, Actas, pp 137-148

Figueiredo de A.A.J., Barros A.M., Eulálio Filho A., Rodrigues A.P., Barreto de F.B., Pimentel B.G., Couto J.G.P., Reichel J.L., Costa G.S.A., De Rezende Filho S.T., Pastori W.P.Jr.Ribeiro Filho W., Berbert C.O., Olivatti O., De Araújo A.G., Triguis J.A., De Mello J.C.R. 1974. Projeto Alto Guaporé. DNPM/CPRM, Goiânia, 250 pp

Geraldes M.C. 1996. Estudos geoquímicos e isotópicos das mineralizações auríferas e rochas associadas da região de Pontes e Lacerda, MT. Instituto de Geociências, Universidade de Campinas. Dissertação de Mestrado, 104 pp.

Geraldes M.C., Kozuch M., Teixeira. W., Van Schmus W.R. 1997.U-Pb constraints on the origin of Mesoproterozoic granites of Pontes e Lacerda region, SW of Amazon Craton. In: I South American Symposium on Isotope Geology, Extended Abstracts, 126-129

Geraldes M.C., Matos J. B., Ruiz A.S., Fetter A.H., Kozuch M., Van Schmus W.R. Tassinari C.C.G., Teixeira. W. 1999.U-Pb constraints on Proterozoic magmatic arcs
in SW Amazon CRio Alegre Terrainon, Brazil. In: II South American Symposium on in SW Amazon CRio Alegre Tera

Leite J.A.D. 1987. Integrated attempt of geological aspects of east Bolívia and southwest portion of Mato Grosso State, Brazil. In: IGCP- 204 Final Meeting of the Working Group, Carajás, Brazil. Extended Abstracts, pp 113-115.

Leite J.A.D. 1989. Geoquímica das lavas básicas da Sequência Vulcano-Sedimentar Quatro Meninas. Instituto de Geociências, Universidade Federal do Rio Grande do Sul. Dissertação de Mestrado. 75 pp

Leite J.A.D, Saes G.S, Weska R.K. 1985. A Suíte Intrusiva Rio Branco e o Grupo Aguapeí nas serras de Rio Branco e Roncador. In: SBG-Simpósio de Geologia do CentroOeste, 2, Goiânia, Anais, 1:247-255

Leite J.A.D, Saes G.S., Ruiz A.S. 1986. Sequências supra-crustais do tipo greenstone belt no SW de Mato Grosso. In: SBG-Congresso Brasileiro de Geologia, 34, Goiânia, Brev. Com, p. 98

Leite J.A.D., Pinho F.E.C, Néder R.D., Pinho M.A.S.B., Saes G.S. 1999. Is the E-W trending Mesozoic Parecis basin hiding part of the evolution history of the southern portion of the Amazon Craton? In: SBG Núcleo Centro-Oeste, 7, Simp. Geologia do Centro-Oeste, Boletim de Resumos, 110

Litherland M., Annells R.N., Darbyshire D.P.F., Fletcher C.J.N., Hawkins M.P., Klinck B.A., Mitchell W.I., O'Connor E.A., Pitfield P.E.J., Power G., Webb B.C. 1989. The Proterozoic of eastern Bolivia and its relationship to the Andean mobile belt Precambrian Research, 43:157-174

Matos J.B. 1991. Contribuição à geologia de parte da porção meridional do Cráton Amazônico - Região de Rio Alegre, MT. Instituto de Geociências, Universidade de São Paulo, Dissertação de Mestrado, 80 pp

Matos J.B., Schorscher J.H.D. 1997. Tendências geoquímicas da sequência vulcanosedimentar do Rio Alegre, MT. In: SBG-Núcleo Centro-Oeste, Simpósio de Geologia do Centro-Oeste, 6, Cuiabá, Anais, p 26-27
Menezes R.G. de, Silva P.C.S., Silva L.C., Takahashi A.T., Lopes Jr. I., Bezerra J.R.L. 1993. Folha Pontes e Lacerda, SD.21-Y-C-II. CPRM, Brasília, 123 pp.

Monteiro H., Macedo P.M.de, Silva M.D.da, Moraes A.A., Marcheto C.M.L. 1986. O Greesntone Belt do Alto Jaurú. In: SBG-Congresso Brasileiro de Geologia,34,Goiânia, Anais,2:630-647

Pinho F.E.C. 1996.The origin of the Cabaçal Cu-Au Deposit, Alto Jaurú Greenstone Belt Brazil. Faculty of Graduate Studies, The University of Western Ontario. Ph.D Thesis, $211 \mathrm{p}$

Pinho F.E.C., Fyfe W.S., Pinho M.A.S.B. 1997. Early Proterozoic evolution of the Alto Jaru Greenstone Belt, Southern Amazon Craton, Brazil. International Geology Review, 39:220-229.

Pinho M.A.S.B.1993. Geologia, Petrologia e Geoquímica das rochas ocorrentes ao longo do Rio Aguapeí - sudoeste do Cráton Amazônico, Pontes e Lacerda, MT. Instituto de Geociências, Universidade Federal do Rio Grande do Sul, Dissertação de Mestrado, 67pp

Pinho M.A.S.B., Pinho F.E.C., Fyfe W.S., Figueiredo B.R., Toledo F.H. 1995. Some geochemistry aspects of the Alto Jauru Greenstone Belt, southwest of the Amazon CRio Alegre Terrainon, Mato Grosso-Brazil. In: 1995 Annual Meeting of the CRio Alegre Terrainon, Mato Grosso-Brazil. In: 1995 Annual Meeting of the
Geological Society of America, Session 150, Latin America Geology, New Orleans, Abstract, p A427.

Ruiz A.S. 1992. Contribuição à geologia do distrito de Cachoeirinha, MT. Instituto de Geociências. Universidade de São Paulo, São Paulo. Dissertação de Mestrado, 98 p.

Sadowski G.R. \& Bettencourt J.S. 1996. Mesoproterozoic tectonic correlation between eas Laurentia and the western border of the Amazon CRio Alegre Terrainon. Precambrian Research, 76:213-227

Saes G.S. \& Leite J.A.D. 1993. Evolução tectono-sedimentar do Grupo Aguapeí, Proterozóico Médio na porção meridional do Cráton Amazônico: Mato Grosso e oriente boliviano. Revista Brasileira de Geociências, 23:31-38

Saes G.S. \& Fragoso César A.R.S.1994. The Aguapeí Basin (sowthwest Amazonia): Greenville age aulacogen of the Sunsas orogen. SBG-Congresso Brasileiro de GeGreenville age aulacogen of the Sunsas orogen. SBG-Congresso Brasil
ologia, 38, Camboriú, Boletim de Resumos Expandidos, 1:207-209

Saes G.S. \& Fragoso César A.R.S.1996. Acresção de terrenos mesoproterozóicos no SW da Amazônia. In:SBG-Sociedade Brasileira de Geologia, 39, Salvador, Boletim de Resumos Expandidos,

Saes G.S., Leite J.A.D., Weska R.K.1984. Geologia da Folha Jaurú (SD-21-Y-C-III): uma síntese dos conhecimentos. In:SBG-Congresso Brasileiro de Geologia,33, Rio de Janeiro, Anais, 5:213-227

Santos J.O.S., Rizzoto G., Hartmann L.A., McNaughton N.J., Fletcher I.R. 1999. Duas orogêneses principais no sudoeste do Cráton amazônico: evidências através das datações U-Pb em zircão (SHRIMP). In: SBG-NO, Simpósio de Geologia da Amazônia, 6, Manaus, Boletim de Resumos, 506-509

Sato K. 1998. Evolução crustal da Plataforma Sul Americana, com base na geoquímica isotópica $S m-N d$. Instituto de Geociências, Universidade de São Paulo. Tese de PósDoutorado, $260 \mathrm{pp}$

Siqueira L. P. 1989. Bacia dos Parecis. Geociências PETROBRÁS, 3(1/2):3-16.

Tassinari C.C.G., Cordani U.G., Nutman A.P. Van Schmus W.R., Bettencourt J.S., Taylor P.N. 1996. Geochronological systematics on basement rocks from the Rio NegroJuruena Province (Amazon CRio Alegre Terrainon) and tectonic implications. Juruena Province (Amazon CRio Alegre Terational Geology Review, 38:1161-1175

Tassinari C.C.G. \& Macambira M.J.B. 1999. Geochronological provinces of the Amazon CRio Alegre Terrainon. Episodes, 22:174-182

Teixeira W., Tassinari C.C.G., Cordani U.G., Kawashita K. 1989. A review of the geochronology of the Amazon CRio Alegre Terrain: Tectonic Implications. Precambrian Research, 42:213-227.

Contribution IGC-126

Received March 1, 2000

Accepted for publication April 27, 2000 